Studia nad Autorytaryzmem i Totalitaryzmem 42, nr 3

Wrocław 2020

https://doi.org/10.19195/2300-7249.42.3.10

\title{
KAMILA KAMIŃSKA-CHEŁMINIAK
}

ORCID: 0000-0002-6082-0444

Uniwersytet Warszawski

ka.kaminska@uw.edu.pl

\section{Współpraca cenzorów z Urzędem Bezpieczeństwa i Służbą Bezpieczeństwa w Polsce w latach 1945-1989 — wybrane zagadnienia}

\begin{abstract}
Abstrakt: Głównym założeniem artykułu jest przybliżenie zakresu oraz form współpracy cenzorów, zarówno na szczeblu centralnym, jak i lokalnym, z Urzędem Bezpieczeństwa i Służbą Bezpieczeństwa w Polsce w latach 1945-1989. Podstawą tekstu są materiały archiwalne zgromadzone między innymi w Archiwum Akt Nowych, Instytucie Pamięci Narodowej, Archiwum Instytutu Literackiego „Kultura” w Maisons-Laffitte oraz Archiwum Ośrodka KARTA w Warszawie. W artykule wykorzystano również wspomnienia między innymi Tomasza Strzyżewskiego, byłego pracownika delegatury krakowskiej GUKPPiW, uzyskane przez autorkę tekstu, a także cenzora z GUKPPiW oraz urzędu w Opolu.
\end{abstract}

Słowa kluczowe: cenzura, Służba Bezpieczeństwa w Polsce, GUKPPiW, WUKPPiW, PRL.

\section{COOPERATION OF THE CENSORSHIP APPARATUS WITH THE SECURITY SERVICE IN POLAND IN THE YEARS 1945-1989 — SELECTED ISSUES}

\section{Abstract}

The assumption of the article is to give the sense of the scope and forms of cooperation of the censorship apparatus (at the central and district level) with the Security Service in Poland in the years 1945-1989. This article has been based on archival material collected in the Archives of New Files, the Institute of National Remembrance, Archives of the Literature Institute "Culture" in Maisons-Laffitte, and Archives of the "Karta" Center in Warsaw. Also, the article consists of the memoirs of Tomasz Strzyżewski, a former employee of the Krakow delegation of GUKPPiW, obtained by the author of the text, and a censor from GUKPPiW and the office in Opole.

Keywords: censorship, Security Service in Poland, Main Office for the Control of Press, Publication and Performances, Voivodeship Office for the Control of Press, Publication and Performances, PRL. 
Jednym z najsłabiej rozpoznanych i opisanych aspektów działalności cenzury, zarówno na szczeblu centralnym, jak i lokalnym, jest zakres współpracy cenzorów z Urzędem Bezpieczeństwa (UB) i Służbą Bezpieczeństwa (SB). W badaniach poświęconych dziejom najnowszym, w tym cenzurze państwowej w Polsce po II wojnie światowej, problematyka współpracy rzeczonych organów nie była jak dotąd przedmiotem zainteresowania badaczy ${ }^{1}$. Analiza materiałów pozyskanych podczas kwerendy między innymi w Archiwum Akt Nowych, Instytucie Pamięci Narodowej oraz archiwach lokalnych pozwala sformułować tezę, że zakres współpracy cenzorów i funkcjonariuszy UB oraz SB był szerszy, niż wynikałoby to $\mathrm{z}$ (ubogiej) literatury przedmiotu oraz powszechnej wiedzy na temat cenzury. Cenzorzy wykonywali dla UB i SB szereg tak zwanych prac zleconych: analizowali dostarczone im książki, czasopisma, druki ulotne, płyty i przeźrocza; wspólnie z funkcjonariuszami UB/SB brali udział w akcjach wymierzonych w rozmaite środowiska; przekazywali funkcjonariuszom UB/SB wiele cennych informacji, które pomagały w rozpracowaniu operacyjnym redakcji pism kościelnych; w latach pięćdziesiątych XX wieku dokonywali lotnych kontroli bazarów przykościelnych i festynów. Skonfiskowane przez cenzorów, a następnie dostarczone do UB/SB materiały prasowe przykazywano redakcjom pism partyjnych, które wykorzystywały je do ataków między innymi na prasę katolicką.

Cenzura była narzędziem partii podczas kampanii propagandowych wymierzonych w rozmaite środowiska. W latach czterdziestych XX wieku cenzorzy wzięli udział w akcji propagandowej skierowanej przeciw członkom i władzom Polskiego Stronnictwa Ludowego oraz byli odpowiedzialni za likwidację (przejęcie) prasy ludowców, w tym najpopularniejszego periodyku PSL — „Gazety Ludowej”. Cenzorzy współpracowali z UB/SB w zakresie zastraszania dziennikarzy prasy PSL oraz przyczynili się — dostarczając wielu cennych informacji — do serii aresztowań wśród członków redakcji.

Cenzorzy brali udział w procesach jako biegli sądowi, a ich ekspertyzy wielokrotnie cytowano w aktach oskarżenia, niekiedy stanowily one podstawę wyroku. Ten rodzaj ich działalności jest stosunkowo słabo rozpoznanym aspektem funkcjonowania aparatu kontroli. Ekspertyzy pisane przez cenzorów służyły jako dowód w postępowaniach i przyczyniły się do skazania licznej grupy osób (między innymi księży, księgarzy, członków grup wyznaniowych, fotografów, którzy wykonywali i sprzedawali pocztówki świąteczne bez zezwolenia urzędu kontroli,

${ }^{1}$ Wyjątkiem jest książka autorki artykułu i szczątkowe informacje zawarte w nielicznych artykułach oraz zbiorach dokumentów, które o współpracy cenzorów z UB i SB wspominają na marginesie innych opisywanych zdarzeń; zob. m.in. K. Kamińska-Chełminiak, Cenzura w Polsce 1944-1960. Organizacja, kadry, metody pracy, Warszawa 2019; M. Patelski, Cenzura komunistyczna wobec Kościoła katolickiego i prasy katolickiej w Polsce. Casus Ślaska Opolskiego, [w:] Cenzura w PRL. Analiza zjawiska, red. Z. Romek, K. Kamińska-Chełminiak, Warszawa 2017, s. 134-135; idem, , Czujni strażnicy demokracji” ludowej. Urząd cenzury w województwie opolskim 1950-1990, Opole 2019, s. 269-271, 309. 
kominiarzy rozprowadzających kalendarze nieposiadające zezwolenia cenzury oraz innych osób prywatnych). Cenzorzy analizowali książki, czasopisma i druki ulotne dostarczane im przez funkcjonariuszy UB/SB, rzadziej Milicji Obywatelskiej, uzyskane podczas rewizji prywatnych mieszkań, kościołów i redakcji, wydobyte z paczek i listów oraz bagaży podróżnych przekraczających granicę czy też dostarczane przez tajnych współpracowników. Opinia cenzora z Głównego Urzędu Kontroli Prasy, Publikacji i Widowisk (GUKPPiW) przyczyniła się również do skazania Anny Rewskiej w lipcu 1958 roku na trzy lata więzienia. Cenzor z Urzędu Głównego zeznawał przed sądem jako świadek w sprawie. Cenzorzy z GUKPPiW oraz Wojewódzkiego Urzędu Kontroli Prasy, Publikacji i Widowisk (WUKPPiW) ściśle współpracowali z Ministerstwem Bezpieczeństwa Publicznego (MBP). Pracownicy UB, dzięki informacjom uzyskanym od cenzorów lub tajnych współpracowników zatrudnionych między innymi w redakcjach, wstrzymywali lub inicjowali kampanie medialne oraz wpływali na bieg pracy dziennikarzy. Informacje dotyczące dziennikarzy podejmujących zakazane tematy, w szczególności co do radzieckich zbrodni, były gromadzone przez naczelników terenowych oddziałów cenzury i przekazywane funkcjonariuszom UB/SB. Cenzorzy zastraszali dziennikarzy prasy katolickiej, tworząc $w$ redakcjach atmosferę niepewności oraz obawy o własne życie. Konsekwencją tego typu współpracy były represje wymierzone na ogół w księży katolickich, siostry zakonne, członków redakcji wybranych pism oraz grup wyznaniowych. Artykuły konfiskowane przez pracowników kontroli były przekazywane, w kilku kopiach, do Departamentu V MBP, który zajmował się rozpracowywaniem legalnych partii i organizacji społecznych. Funkcjonariusze tego departamentu sporządzali charakterystyki członków redakcji pism katolickich pod kątem możliwości agenturalnego dotarcia do zespołu redakcyjnego. Próbowano werbować dziennikarzy rzeczonych pism, a jeśli to nie było możliwe, to współpracowników lub inne osoby zbliżone do redakcji (na przykład sprzątaczki, woźnych) ${ }^{2}$. Cenzorzy nierzadko odgrywali rolę nieformalnych współpracowników, którzy udzielali informacji na temat swoich kontaktów z dziennikarzami. Naczelnicy WUKPPiW, z racji piastowanego stanowiska, byli w stałym kontakcie z MBP/MSW. Sporządzali dla ministerstwa opracowania, raporty, notatki ze spotkań z dziennikarzami oraz przekazywali informacje, które pomagały w operacyjnym rozpracowywaniu redakcji oraz poszczególnych osób.

$* * *$

Podstawą niniejszego artykułu są materiały archiwalne zgromadzone między innymi w Archiwum Akt Nowych, Instytucie Pamięci Narodowej, Archiwum Instytutu Literackiego „Kultura” w Maisons-Laffitte oraz Archiwum Ośrodka

2 Instytut Pamięci Narodowej Biuro Udostępniania (dalej: IPN BU) 0648/154/1, t. 1, s. 34 n. 
KARTA w Warszawie. W tekście wykorzystano również wspomnienia między innymi Tomasza Strzyżewskiego, byłego pracownika delegatury krakowskiej GUKPPiW, uzyskane przez autorkę tekstu, a także cenzora z GUKPPiW oraz urzędu w Opolu. Głównym założeniem artykułu jest przybliżenie zakresu oraz form współpracy cenzorów (różnego szczebla) z Urzędem Bezpieczeństwa i Służbą Bezpieczeństwa w Polsce w latach 1945-1989. Ze względu na szeroki zakres problemowy zagadnienia autorka opracowania skoncentrowała się na kilku wybranych przykładach ilustrujących skalę oraz zakres kontaktów cenzorów i funkcjonariuszy aparatu represji.

$* * *$

Urząd cenzury cywilnej (obok już istniejącej wojskowej) powstał na ziemiach polskich jeszcze podczas II wojny światowej. Dnia 19 stycznia 1945 roku z rozkazu Ministra Bezpieczeństwa Publicznego Stanisława Radkiewicza utworzono Centralne Biuro Kontroli Prasy (CBKP). Podlegało ono Ministerstwu Bezpieczeństwa Publicznego, a pierwsi cenzorzy byli rekrutowani spośród funkcjonariuszy Urzędów Bezpieczeństwa $^{3}$. W dniu 15 listopada 1945 roku CBKP przekształcono w Główny Urząd Kontroli Prasy, Publikacji i Widowisk i przekazano pod zwierzchnictwo Prezydium Rady Ministrów, choć w praktyce nadal podlegał on Jakubowi Bermanowi ${ }^{4}$. Wyłączenie GUKPPiW z MBP i afiliowanie go przy Prezydium Rady Ministrów miało na celu odsunięcie urzędów bezpieczeństwa od znacznego wpływu na najważniejsze decyzje prasowe. Zmiana usytuowania miała również zapobiec kojarzeniu GUKPPiW z aparatem terroru, choć w praktyce zmiana statusu nie oznaczała zerwania kontaktów z aparatem bezpieczeństwa. GUKPPiW ściśle współpracował z MBP (a następnie z Komitetem do Spraw Bezpieczeństwa Publicznego i MSW) zarówno w latach czterdziestych i pięćdziesiątych XX wieku, jak i w kolejnych dekadach, choć to właśnie lata powojenne i pierwsza połowa lat

3 Archiwum Akt Nowych (dalej: AAN), Główny Urząd Kontroli Prasy, Publikacji i Widowisk (dalej: GUKPPiW), sygn. 24, Biuletyn Informacyjno-Instrukcyjny nr 1 (I 1955) — nr 11/12 (XII 1955), s. 1-2. Do 1954 roku (wówczas nastąpił podział MBP na Ministerstwo Spraw Wewnętrznych i Komitet do Spraw Bezpieczeństwa Publicznego) Ministerstwu Bezpieczeństwa Publicznego podlegało wiele formacji: urzędy bezpieczeństwa publicznego, Milicja Obywatelska, Korpus Bezpieczeństwa Wewnętrznego, Wojska Ochrony Pogranicza, Ochotnicza Rezerwa Milicji Obywatelskiej, Straż Przemysłowa, Służba Więzienna. Najważniejszym jednak organem MBP był aparat bezpieczeństwa. W listopadzie 1944 roku liczył około 2,5 tysiąca funkcjonariuszy, w końcu 1945 roku około 24 tysiące, w 1953 roku już ponad 33 tysiące; Aparat bezpieczeństwa w Polsce. Kadra kierownicza 1944-1956, t. 1, red. K. Szwagrzyk, Warszawa 2005, s. 20.

${ }^{4}$ Rozkaz opublikowano w Ksiega bezprawia. Akta normatywne kierownictwa Resortu Bezpieczeństwa Publicznego (1944-1956), wyb. i oprac. B. Kopka, wstęp A. Paczkowski, Warszawa 2011, s. 75-76. 
pięćdziesiątych XX wieku stanowią okres najintensywniejszej współpracy cenzorów z Urzędem Bezpieczeństwa i Służbą Bezpieczeństwa.

\section{Cenzorzy jako informatorzy UB/SB}

Cenzorzy pełnili funkcje nieformalnych informatorów, którzy udzielali informacji na temat swoich kontaktów z dziennikarzami. Funkcjonariusze UB/SB, dzięki informacjom uzyskanym od cenzorów lub tajnych współpracowników zatrudnionych między innymi w redakcjach, wstrzymywali lub inicjowali kampanie medialne oraz wpływali na bieg pracy dziennikarzy. Kiedy w lipcu 1947 roku funkcjonariusz V Departamentu MBP otrzymał informację od tajnego współpracownika pracującego w „Tygodniku Powszechnym”, że redakcja planuje rozpoczęcie kampanii prasowej na temat zbrodni katyńskiej, „poczyniono kroki zapobiegawcze w Urzędzie Kontroli Prasy, żądając natychmiastowego alarmowania [...] o najmniejszej wzmiance o Katyniu"s. W okresie stalinizmu pracownicy kontroli nie ograniczali się do cenzurowania prasy, ale stawiali redakcjom żądania, by umieszczały w pismach konkretne polityczne treści, na przykład artykuły potępiające hitlerowców za zbrodnię katyńską. O reakcji redaktora naczelnego gazety naczelnicy urzędów cenzury informowali Urząd Bezpieczeństwa. Taka sytuacja miała miejsce w przypadku tygodnika „Niedziela”, gdzie do artykułu pod tytułem Nie zabijaj, poświęconego zbrodni katyńskiej, cenzor samowolnie, bez konsultacji z autorem tekstu oraz redakcją, dodał informację, że sprawcami tego mordu byli hitlerowcy. Ksiądz Antoni Marchewka, redaktor naczelny pisma, nie zgodził się na taką ingerencję i postanowił artykuł usunąć en bloc. Naczelnik urzędu odparł, że jeśli dany artykuł, z jego poprawkami, nie znajdzie się w numerze, wówczas wstrzyma cały nakład. Z obszernej notatki sporządzonej w marcu 1952 roku przez naczelnika urzędu kontroli, a następnie przesłanej do MBP wynika, że ks. Marchewka bardzo kluczył w sprawie zbrodni katyńskiej i próbował nakłonić cenzora do wycofania artykułu z numeru ${ }^{6}$. Przekonywał naczelnika MUKPPiW w Częstochowie, że nie czyta prasy amerykańskiej i nie wie o śledztwie w sprawie zbrodni katyńskiej. Dodał również, że nie wie, kto był sprawcą mordu, ponieważ nie było go przy tym, jak ich zabijano ${ }^{7}$. Rzecz jasna ks. Marchewka doskonale wiedział, że zbrodnię popełniło NKWD, ale z obawy o własne życie i dobro redakcji wolał nie ujawniać swoich poglądów. W latach stalinizmu można było bowiem trafić do więzienia na osiem lat za opowiadanie „reakcyjnych” dowcipów, jak miało to miejsce w przypadku robotnika, który został skazany przez sąd wojskowy w 1952 roku, więc tym bardziej groziło to za

5 Sprawozdania Sekcji 5 Wydziału V Wojewódzkiego Urzędu Bezpieczeństwa Publicznego w Krakowie 1946-1952, red. F. Musiał, Kraków 2008, s. 146.

${ }^{6}$ IPN BU 0648/154/1, t. 1, s. 103.

7 Ibidem. 
mówienie prawdy o Katyniu ${ }^{8}$. Ostatecznie sprawę zamknęła decyzja Antoniego Bidy, dyrektora Urzędu do Spraw Wyznań, który wyraził zgodę na druk egzemplarza bez rzeczonego artykułu?

Informacje dotyczące dziennikarzy podejmujących „niecenzuralne” tematy, w szczególności dotyczące radzieckich zbrodni, były gromadzone przez naczelników terenowych oddziałów cenzury i przekazywane funkcjonariuszom UB/ SB. W latach stalinizmu naczelnicy wojewódzkich urzędów kontroli co miesiąc opisywali w sprawozdaniach dla GUKPPiW swoje kontakty z redakcjami prasy katolickiej, uwzględniając w nich takie informacje, jak liczba ingerencji na łamach rzeczonych periodyków, tematy poruszane przez redakcje oraz stosunek poszczególnych dziennikarzy do poleceń cenzorów. W przypadku niektórych gazet (na przykład „Tygodnika Powszechnego”) dyrektorzy urzędów wojewódzkich dość szczegółowo kreślili sylwetki redaktorów, którzy nierzadko z determinacją bronili swoich racji. O niepokornych postawach cenzorzy informowali UB/SB, gdzie analizowano poszczególne przypadki i wyciągano odpowiednie wnioski. W przypadku „Tygodnika Powszechnego” już pod koniec 1946 roku wszczęto przeciwko redakcji sprawę rozpracowania operacyjnego o kryptonimie „Noc”, a jednym ze źródeł informacji o zatrudnionych tam osobach byli cenzorzy ${ }^{10}$. Od tamtego czasu rozpoczęły się próby werbunku członków redakcji, administracji pisma lub osób związanych z „Tygodnikiem Powszechnym”, w czym pomagali, świadomie i nieświadomie, cenzorzy z WUKPPiW w Krakowie.

Artykuły konfiskowane przez cenzorów były przekazywane w kilku kopiach do Departamentu V MBP, który zajmował się rozpracowywaniem legalnych partii i organizacji społecznych. Funkcjonariusze tego departamentu sporządzali charakterystyki członków redakcji pism katolickich pod kątem możliwości agenturalnego dotarcia do zespołu redakcyjnego. Próbowano werbować dziennikarzy pism katolickich, a jeśli to nie było możliwe, to współpracowników lub inne osoby zbliżone do redakcji (na przykład sprzątaczki, woźnych) ${ }^{11}$. Naczelnicy WUKPPiW, z racji wykonywanego stanowiska, byli w stałym kontakcie $\mathrm{z}$ funkcjonariuszami MBP. Sporządzali dla nich opracowania, raporty, notatki ze spotkań z dziennikarzami oraz przekazywali wiele cennych informacji, które pomagały w operacyjnym rozpracowywaniu redakcji oraz innych, niezwiązanych z prasą, osób ${ }^{12}$.

W styczniu 1953 roku naczelnik WUKPPiW w Poznaniu, w sprawozdaniu napisanym dla GUKPPiW, informował o charakterze współpracy z funkcjonariuszami UB:

8 A. Werblan, Stalinizm w Polsce, Warszawa 2009, s. 70.

9 A. Marchewka, „...Nadejdzie kiedyś dzień wolności”. Wspomnienia, Częstochowa 2008, s. 27.

10 IPN BU 0648/154/1 t. 1, s. 126.

11 Ibidem, s. 34 n.

12 Ibidem, s. 147. 
Władze bezpieczeństwa zasygnalizowały nam ujęcie osoby, która wykonywała sposobem fotograficznym i rozpowszechniała obrazki o wrogiej treści ${ }^{13}$. Obrazki przedłożono nam do wglądu i zaopiniowania. Wg dotychczasowych wyników kontroli powielaczy i druków nie zaobserwowaliśmy prób wydania pism powielanych drogą pomijającą naszą kontrolę. Fakt ten potwierdzają władze bezpieczeństwa, z którymi pozostajemy w stałym kontakcie — wykryte przez nie wrogie druki są odbitkami maszynopisowymi ${ }^{14}$.

Cenzorzy zastraszali dziennikarzy prasy katolickiej, tworząc w redakcjach atmosferę niepewności oraz obawy o własne życie. W listopadzie 1951 roku redaktor „Gościa Niedzielnego” podczas rozmowy z naczelnikiem WUKPPiW w Katowicach usłyszał: „Obserwujemy waszą linię polityczną. Mamy materiał i gromadzimy go. W swoim czasie będziecie musieli zdać sprawę - ale to już nie przede mną"15. Ze wspomnień ks. Antoniego Marchewki, redaktora naczelnego „Niedzieli”, wynika, że polemika z cenzorami była utrudniona ze względu na ich fanatyczny wręcz antyklerykalizm i odporność na argumenty. Poza tym w cenzurze nie przepadano za kłótliwymi redaktorami, niepogodzonymi z decyzją pracowników kontroli. Wystarczył więc jeden sygnał naczelnika WUKPPiW, aby Urząd Bezpieczeństwa „ukrócił wyskoki” nielubianego redaktora.

\section{Oceny prasy, książek, druków ulotnych i rękopisów na zlecenie $\mathrm{UB} / \mathrm{SB}$}

Stałym zajęciem cenzorów, zarówno na szczeblu wojewódzkim, jak i centralnym, była ocena publikacji dostarczonych przez funkcjonariuszy UB/SB. Książki były rekwirowane podczas rewizji w prywatnych mieszkaniach, kościołach, plebaniach, antykwariatach oraz w trakcie kontroli paczek przysyłanych z zagranicy, a następnie oceniane pod kątem ich politycznej „szkodliwości”. Zarekwirowane w ten sposób publikacje trafiały do urzędów cenzury, a następnie - po przeanalizowaniu - zwracano je funkcjonariuszom aparatu bezpieczeństwa. Na przykład WUKPPiW w Opolu w marcu 1953 roku przeanalizował na zlecenie Wojewódzkiego Urzędu Bezpieczeństwa Publicznego (WUBP) 16 książek $^{16}$. W maju pełniąca obowiązki naczelnika tego samego urzędu otrzymała z WUBP zlecenie oceny kolejnej partii książek, tym razem po niemiecku, jednak ze względu na brak cenzora posługującego się tym językiem musiała odmówić ${ }^{17}$. W czerwcu opolski

13 Chodzi o obrazki z wizerunkami świętych.

14 AAN, GUKPPiW, sygn. 11, sprawozdania okresowe WUKPPiW za rok 1953 (Olsztyn, Opole, Poznań, Rzeszów, Szczecin, Wrocław); recenzje książek, pisma instrukcyjne, k. 119.

15 Represje wobec duchowieństwa górnośląskiego w latach 1939-1956 w dokumentach, wyb., wstęp i oprac. K. Banaś, A. Dziurok, Katowice 2003, s. 196.

16 AAN, GUKPPiW, sygn. 11, sprawozdania okresowe WUKPPiW za rok 1953 (Olsztyn, Opole, Poznań, Rzeszów, Szczecin, Wrocław); recenzje książek, pisma instrukcyjne, k. 63.

17 Ibidem, k. 68. 
urząd przeanalizował ,antyustrojowe książkowe i broszurowe materiały niemieckie częściowo przemycone z Trizonii" ${ }^{18}$. W sierpniu urząd w Opolu otrzymał z WUBP kolejną partię książek i broszur z Niemiec Zachodnich. Jak pisał cenzor, który je analizował: „we wszystkich przypadkach chodziło o oceny niemieckich naszpikowanych wrogą treścią materiałów książkowych i prasowych"19. We wrześniu WUBP w Opolu ,obok antypolskich i antypostępowych książek przedłożył również do oceny kilkadziesiąt egzemplarzy rewizjonistycznych, z Trizonii przemycanych czasopism, w tym kilka zdekompletowanych roczników. Były to przeważnie polakożercze piśmidła ubrane $\mathrm{w}$ ornamentykę religijną" ${ }^{\prime 20}$. Z comiesięcznych sprawozdań WUKPPiW wysyłanych w latach stalinizmu do Urzędu Głównego wynika, że poszczególne urzędy cenzury na zlecenie WUBP analizowały rokrocznie w latach pięćdziesiątych XX wieku od kilkudziesięciu do kilkuset egzemplarzy książek i czasopism (nie wliczając w to płyt gramofonowych).

Ze wspomnień dyrektora WUKPPiW w Opolu, Eugeniusza Kanioka, który kierował urzędem w latach 1976-1990, wynika, że również w latach siedemdziesiątych i osiemdziesiątych XX wieku cenzorzy analizowali książki i czasopisma na zlecenie SB. Były cenzor wspominał: ,przychodzili do mnie z książkami zarekwirowanymi podczas rewizji. Przynosili stosy, jakby chcieli powiedzieć: »Męcz się, człowieku «"21.

Konsekwencją współpracy UB/SB i cenzorów w zakresie oceny prasy, książek, druków ulotnych i rękopisów były represje wymierzone głównie w księży katolickich, siostry zakonne, członków redakcji oraz grup religijnych (na przykład zielonoświątkowców, Świadków Jehowy). Jednym z przykładów może być sprawa ks. Józefa Wojaczka, którego funkcjonariusze UB aresztowali we wrześniu 1952 roku. Podczas rewizji dokonanej w jego mieszkaniu znaleziono maszynopis i rękopis pamiętników księdza, broszury, dwanaście książek oraz periodyków katolickich. Książki oraz rękopisy, które przekazano cenzorom w WUKPPiW w Opolu, stały się koronnym dowodem przeciwko duchownemu. W ocenie aparatu kontroli pisma zawierały mnóstwo wrogich politycznie informacji. Wspomnienia księdza dotyczące wejścia Armii Czerwonej na Śląsk w 1945 roku uznano za ,wybitnie wrogie, dywersyjne i szerzące fałszywą propagandę w stosunku do ZSRR i Armii Radzieckiej. Okres przebywania tu Armii Radzieckiej przedstawiają jako okres mordów, gwałtów i grabieży. Całość pamiętników to stek wrogich kłamstw, kolportowanie których [...] jest dywersją"22. Obszerne fragmenty ekspertyzy cenzorskiej znalazły się w uzasadnieniu wyroku, który wydał Wojskowy Sąd Rejonowy w Opolu w marcu 1953 roku przeciwko ks. Wojaczkowi. Księdza

\footnotetext{
18 Ibidem, k. 72.

19 Ibidem, k. 80 .

20 Ibidem, k. 90.

21 Wewnętrznie rozdarty, wywiad z Eugeniuszem Kaniokiem, [w:] B. Torański, Knebel. Cenzura w PRL-u, Warszawa 2016, s. 248.

22 Cyt. za: M. Patelski, Cenzura komunistyczna..., s. 134.
} 
oskarżono o chęć obalenia przemocą ustroju państwa polskiego poprzez przechowywanie oraz rozpowszechnianie wydawnictw i skazano na sześć lat więzienia. Po wyjściu na wolność w marcu 1955 roku ks. Wojaczek nadal był obiektem obserwacji SB, ostatecznie we wrześniu 1958 roku wyemigrował do RFN ${ }^{23}$.

W podobnej sytuacji znalazł się ks. Franciszek Trela SJ, opolski duszpasterz akademicki, w którego mieszkaniu funkcjonariusze Urzędu Bezpieczeństwa znaleźli wiele książek zawierających „wrogą treść” oraz „nieprawomyślne” rękopisy kazań. W grudniu 1955 roku aresztowano księdza, a zarekwirowane publikacje trafiły do WUKPPiW w Opolu, gdzie poddano je analizie. W procesie sądowym, który rozpoczął się w marcu 1956 roku, uczestniczył, w charakterze biegłego sądowego, cenzor opolskiego urzędu kontroli. Pracownik WUKPPiW wydał orzeczenie niekorzystne dla księdza, będące najprawdopodobniej podstawą wyroku, wskazujące na wrogi i antypaństwowy charakter jego kazań oraz literatury zarekwirowanej w prywatnym mieszkaniu ${ }^{24}$. Ksiądz Trela został skazany na trzy lata za „nadużywanie wolności wyznania i sumienia w celach wrogich ustrojowi Rzeczpospolitej Polskiej”. W wyniku amnestii w maju 1956 roku duchowny opuścił więzienie ${ }^{25}$.

W latach pięćdziesiątych XX wieku cenzorzy wspólnie z funkcjonariuszami Urzędów Bezpieczeństwa przeszukiwali prywatne antykwariaty i księgarnie w poszukiwaniu książek znajdujących się na indeksie cenzury lub wzbudzających podejrzenia co do zgodności z polityką partii. Na terenach Ziem Zachodnich była to częstokroć literatura niemieckiej proweniencji, nielegalnie krążąca wśród prywatnych osób oraz sprzedawana „spod lady” w antykwariatach. Zarekwirowane podczas kontroli książki były następnie wysyłane do Urzędu Głównego w Warszawie, a tam analizowane pod kątem ich „dywersyjnych” właściwości.

\section{Cenzor jako biegły sądowy w procesie Anny Rewskiej}

Cenzorzy współpracowali ze Służbą Bezpieczeństwa również w zakresie oceny publikacji zarekwirowanych w mieszkaniu Anny Rewskiej, która w lipcu 1958 roku została skazana na trzy lata więzienia za rozpowszechnianie paryskiej „Kultury” oraz pozostałych publikacji Instytutu Literackiego, zawierających zdaniem sądu „fałszywe wiadomości, mogące wyrządzić istotną szkodę interesom Państwa Polskiego i obniżyć powagę jego naczelnych organów"26.

Rewska utrzymywała kontrakty z Jerzym Giedroyciem od marca 1956 roku, gdy rozpoczęła się między nimi wymiana listów. Osobiście poznali się w kwietniu

23 Ibidem, s. 135.

24 M. Patelski, ,Czujni strażnicy demokracji” ludowej..., s. 271.

25 Ibidem.

${ }^{26}$ Archiwum Ośrodka KARTA w Warszawie (dalej: AOK), AO III/214K.11.39, akt oskarżenia A. Rewskiej, s. 2-3. Zob. również Sąd orzekt..., Paryż 1972, s. 25-30. 
1957 roku, kiedy Rewska odwiedziła redaktora w Maisons-Laffitte ${ }^{27}$. U redaktora zamawiała liczne książki oraz egzemplarze czasopisma, które następnie kolportowała wśród znajomych. Na prośbę Giedroycia wysyłała mu materiały powielaczowe, nielegalnie krążące po Warszawie (na przykład zablokowany przez cenzurę artykuł pod tytułem Śmierć bogów Leszka Kołakowskiego, który miał się ukazać w „Nowej Kulturze”), sprawozdania z dyskusji Klubu Krzywego Koła, wycinki z prasy krajowej na temat „Kultury”, książki telefoniczne Warszawy, Krakowa, Gdańska, Łodzi i Wrocławia, egzemplarze czasopism „Po prostu”, „Od Nowa”, „Walka Młodych” oraz „Za i Przeciw”, a także spisy repatriantów z ZSRR i byłych członków Armii Krajowej znajdujących się w trudnej sytuacji materialnej ${ }^{28}$. Publikacje Instytutu Literackiego kolportowała głównie wśród znajomych, a ulotki otrzymane od Giedroycia wysyłała na adres losowo wybranych (z książki telefonicznej) domów studenckich na terenie kraju oraz do redakcji wybranych pism ${ }^{29}$. Przepisywała na maszynie poszczególne artykuły z „Kultury” (na przykład Juliusza Mieroszewskiego), które przekazywała znajomym ${ }^{30}$.

Dnia 30 stycznia 1958 roku do mieszkania Rewskiej weszli funkcjonariusze Służby Bezpieczeństwa. Skonfiskowali między innymi kilkadziesiąt ulotek, które otrzymała od Giedroycia. Zarekwirowane publikacje trafiły do cenzorów. Akt oskarżenia Rewskiej w znacznej części opierał się na ekspertyzie cenzora z Głównego Urzędu Kontroli Prasy, Publikacji i Widowisk, który uczestniczył w procesie w charakterze biegłego sądowego. Książki, które dostarczono mu do analizy (między innymi Nowa klasę wyzyskiwaczy Milovana Dżilasa), uznał za antypaństwowe, kłamliwie uzasadniające tezę, że ustrój socjalistyczny został narzucony wyłącznie przez przemoc radziecką. Cenzor, który wziął udział w procesie, był de facto sędzią we własnej sprawie, gdyż znaczną część ekspertyzy stanowiła polemika z publikacjami „Kultury” na temat cenzury w Polsce. Cenzor starał się udowodnić, że zarzuty formułowane przez publicystów „Kultury”, wskazujące na ograniczenie wolności słowa i druku w Polsce oraz wzmożoną aktywność aparatu kontroli, to „kłamliwe jątrzenie”. Dnia 4 lipca 1958 roku Sąd Wojewódzki dla miasta stołecznego Warszawy wydał wyrok trzech lat więzienia, wliczając w poczet kary okres aresztowania. W uzasadnieniu stwierdzono, że zgodnie z opinią biegłego - kolportowane przez Rewską druki nie posiadały debitu ze względu na „całkowitą negację marksizmu, jego podstawowych założeń, dyktatury proletariatu, roli Partii, internacjonalizmu". Zdaniem sądu artykuły publikowane w „Kulturze”, wydawnictwa i ulotki Instytutu Literackiego zawierały „treść godzącą w istotę ustroju socjalistycznego ${ }^{31}$.

27 Archiwum Instytutu Literackiego w Maisons-Laffitte (dalej: AIL ML), list A. Rewskiej do J. Giedroycia, 19.03.1956.

28 AOK, AO III/214K.11.39, protokół przesłuchania podejrzanej A. Rewskiej, s. 8.

${ }^{29}$ Ibidem, s. 46-47.

30 Ibidem, s. 8.

31 Sad orzekt..., s. 44-45. Adwokat Rewskiej - Aniela Steinsbergowa — zaskarżyła wyrok do Sądu Najwyższego, w wyniku czego 10 listopada 1958 roku sąd uchylił go i przypisał oskarżonej 


\section{Rozpracowanie operacyjne Stanisława Cata-Mackiewicza}

Cenzorzy z GUKPPiW współpracowali ze Służbą Bezpieczeństwa również w zakresie rozpracowania operacyjnego i procesu Stanisława Cata-Mackiewicza. Pisarz, po kilkunastu latach pobytu w Londynie, 14 czerwca 1956 roku powrócił do kraju. Tuż po powrocie nie krył zadowolenia ze swojej decyzji. W liście do przyjaciela, Michała Kryspina Pawlikowskiego, pisał, iż z każdym dniem coraz bardziej się cieszy, że wrócił ${ }^{32}$. W listopadzie 1957 roku pisał: „Tu [w Warszawie] uważam, że jestem między swymi" ${ }^{33}$. Z biegiem czasu jednak zmienił zdanie, a głównym tego powodem były coraz większe problemy z cenzurą państwową, które doprowadziły Mackiewicza do nawiązania kontaktów z Giedroyciem. Właściwie już kilka miesięcy po przyjeździe zaczął narzekać na jej działalność. Podczas spotkania z Melchiorem Wańkowiczem w sierpniu 1956 roku ,ryczał jak odyniec”, że cenzura „dobiera mu się do skóry”34. Cenzura niweczyła mu plany wydawnicze i deformowała twórczość. Mackiewicz, o czym informowali tajni współpracownicy SB, bezpardonowo krytykował działalność urzędu. Czuł się coraz bardziej zawiedziony sytuacją w kraju, niemożnością uprawiania takiej publicystyki, do której przywykł w przedwojennej Polsce i na emigracji, oficjalnym zakłamaniem władz oraz szalejącą cenzurą. Czuł się rozczarowany, gdyż wracając do kraju, liczył, że będzie mógł pisać i publikować, a okazało się, że książka będąca jego najlepszym krajowym dziełem — Polityka Becka, którą ostatecznie wydał w 1964 roku Instytut Literacki - nie mogła ukazać się drukiem ${ }^{35}$. Działalność pisarza budziła coraz większe zastrzeżenia władzy, która publiczną krytykę cenzury oraz polityki kulturalnej państwa traktowała na równi z „uprawianiem propagandy wrogiej ustrojowi” ${ }^{36}$. Czarę goryczy przelał List 34 podpisany przez Mackiewicza oraz seria kilku artykułów opublikowanych przezeń pod pseudonimem Gaston de Cerizay w paryskiej „Kulturze”, w szczególności tekst pod tytułem Polska Gomulki i list 34, w którym zrelacjonował przebieg posiedzenia Zarządu Głównego Związku Literatów Polskich ${ }^{37}$.

SB zamierzała uniemożliwić Mackiewiczowi kontakty z „Kulturą” i jej współpracownikami oraz doprowadzić do izolacji pisarza w środowisku literackim.

przestępstwo z art. 24 małego kodeksu karnego, zagrożonego karą pięciu lat więzienia. Jednocześnie, mając na uwadze zdrowie oskarżonej, wymagającej intensywnego leczenia, okoliczność łagodzącą w postaci małego dziecka oraz dwukrotne odznaczenie Krzyżem Walecznych, zasądził karę jednego roku i sześciu miesięcy więzienia w zawieszeniu na trzy lata. Po jedenastu miesiącach Rewska wyszła na wolność.

32 J. Jaruzelski, Stanisław Cat-Mackiewicz 1896-1966. Wilno-Londyn-Warszawa, Warszawa 1987, s. 296.

33 M.K. Pawlikowski, Stanisław Mackiewicz w listach do przyjaciela, „Kultura” 5, 1967, s. 72.

34 Cyt. za: Melchior Wańkowicz w liście do Marii Wańkowicz, [w:] J. Siedlecka, Obława. Losy pisarzy represjonowanych, Warszawa 2005, s. 247.

35 IPN BU, 01251/533, doniesienie TW „Piotra”, 20.10.1964.

36 Ibidem.

37 G. de Cerizay, Polska Gomulki i list 34, „Kultura” 10, 1964, s. 13-26. 
W związku z tym już na początku 1965 roku wystąpiła do Prokuratury Wojewódzkiej w Warszawie o wydanie pozwolenia na zajęcie korespondencji wychodzącej i przychodzącej na adres domowy Mackiewicza ${ }^{38}$. Jednocześnie założono w mieszkaniu pisarza podsłuch pokojowy oraz telefoniczny ${ }^{39}$, a następnie wszczęto sprawę operacyjnego rozpracowania i zarejestrowano, w Wydziale I Biura „C” MSW (prowadzącym ewidencję osób będących w zainteresowaniu operacyjnym SB), sprawę o kryptonimie „Autor” 40.

Rolą dyrekcji GUKPPiW było informowanie Służby Bezpieczeństwa o aktywności literackiej i publicystycznej pisarza, w szczególności zaś o „niecenzuralnych" tematach poruszanych w twórczości, odrzuconych tekstach, poglądach polityczno-społecznych Mackiewicza oraz swoistości stylu pisarskiego (zwrotach/metaforach charakterystycznych dla stylu pisarza). Dzięki informacjom uzyskanym od cenzorów Służba Bezpieczeństwa wiedziała, że anegdota o Churchillu użyta w artykule Polska Gomulki i list 34 jest autorstwa Mackiewicza, który chciał ją przytoczyć w książce na temat polityki Becka, lecz jego plany zablokowała cenzura ${ }^{41}$. Warto pamiętać, że dyrektorzy WUKPPiW oraz Urzędu Głównego przekazywali funkcjonariuszom SB nie tylko „suche” informacje, ale również kopie ocenzurowanych lub wstrzymanych w całości artykułów/maszynopisów książek do samodzielnej analizy oraz wykorzystania w pracy operacyjnej przeciwko wybranym osobom i środowiskom.

Dnia 22 czerwca 1965 roku wiceprokurator Prokuratury Generalnej w Warszawie, na podstawie materiałów dostarczonych przez Służbę Bezpieczeństwa, wniósł do sądu akt oskarżenia przeciwko Stanisławowi Mackiewiczowi ${ }^{42}$. W akcie oskarżenia stwierdzono, że informacje zawarte we wspomnianych tekstach, dotyczące stosunków społeczno-politycznych panujących w PRL oraz relacji między PRL a ZSRR, mogły wyrządzić państwu polskiemu istotną szkodę. Tym samym Mackiewicz dopuścił się przestępstwa szczególnie niebezpiecznego w okresie odbudowy państwa (art. 23 ust. 1 dekretu z 13 czerwca 1946 roku o przestępstwach szczególnie niebezpiecznych w okresie odbudowy Państwa), podlegającego karze co najmniej trzech lat więzienia ${ }^{43}$. Ze względu jednak na stan zdrowia oskarżonego rozpatrzenie sprawy zawieszono. W listopadzie 1965 roku Mackiewicz ponownie został oskarżony o przestępstwo rozpowszechniania fałszywych wiadomości dotyczących stosunków społeczno-politycznych

38 IPN BU 01251/533, notatka służbowa, 30.04.1965.

39 IPN BU 01251/533, pismo do MSW, 14.02.1965.

40 IPN BU 01251/533, wniosek o założenie sprawy, 28.01.1965.

41 IPN BU 01251/533, notatka opracowana na podstawie opinii t.w. dotycząca autorstwa publikacji „Kultury” paryskiej, podpisywanych pseudonimem „Gaston de Cerizay”, 29.10.1964.

42 IPN BU 01251/533, akt oskarżenia, listopad 1965.

43 Dz.U. z 1946 r. Nr 30, poz. 192. 
panujących w PRL. W lutym 1966 roku prokurator miasta stołecznego Warszawy postanowił umorzyć śledztwo z powodu śmierci podejrzanego ${ }^{44}$.

\section{Analiza publikacji grup wyznaniowych}

W latach czterdziestych i pięćdziesiątych XX wieku cenzorzy z Wojewódzkich Urzędów Kontroli Prasy, Publikacji i Widowisk niemal co miesiąc, na zlecenie UB/SB, analizowali publikacje grup wyznaniowych (książki, czasopisma, płyty z wykładami oraz przeźrocza) kolportowane przez ich członków. Były to najczęściej publikacje Świadków Jehowy, rzadziej zielonoświątkowców i adwentystów. Fragmenty recenzji cenzorskich wykorzystywano w uzasadnieniach wyroków sądowych wydawanych przeciwko członkom rzeczonych grup. Ze sprawozdań cenzorskich wynika, że niektóre urzędy kontroli miesięcznie analizowały nawet do kilkudziesięciu egzemplarzy.

Gros procesów sądowych przeciwko Świadkom Jehowy miało miejsce na początku lat pięćdziesiątych XX wieku. W czerwcu 1950 roku władze rozpoczęły akcję masowych aresztowań Świadków Jehowy, połączoną z zaborem mienia, która objęła większość wyznawców. Podczas procesów pokazowych, w których oskarżano Świadków Jehowy o szpiegostwo na rzecz USA, jako dowód przedstawiano literaturę religijną uprzednio zrecenzowaną przez cenzorów. W marcu 1951 roku odbył się proces kierownictwa związku wyznaniowego, w którym zapadły wyroki dożywotnego więzienia (żądano nawet kary śmierci), a w 1952 roku nastąpiła kolejna fala aresztowań ${ }^{45}$. Świadkowie Jehowy nie przerwali działalności misyjnej, nadal wydawali i kolportowali literaturę religijną, która była dostarczana przez informatorów do Urzędu Bezpieczeństwa, a następnie przekazywana cenzorom do oceny. Recenzje dostarczone przez cenzorów z WUKPPiW w Katowicach, występujących w charakterze biegłych sądowych, stanowiły dowód w sprawie przeciwko członkom grupy skazanym przez Sąd Wojewódzki w Katowicach w maju 1952 roku. Czasopismo wydawane przez Świadków Jehowy — „Strażnica” (oraz wersja anglojęzyczna „The Watchtower”) — zostało pozbawione debitu komunikacyjnego decyzją naczelnego dyrektora GUKPPiW z dnia 20 lipca 1950 roku, a w 1955 roku prezes GUKPPiW zakazał rozpowszechniania „wszelkich wydawnictw nielegalnej w Polskiej Rzeczypospolitej Ludowej sekty Świadków Jehowy niezależnie od miejsca i daty wykonania"46.

W recenzjach publikacji Świadków Jehowy pisanych na zamówienie UB/ SB cenzorzy pisali, że ich treść jest wroga, kłamliwa, godzi w ustrój państwa, zawiera krytykę ustroju komunistycznego, „zionie nienawiścią do socjalizmu

44 IPN BU 01251/533, postanowienie o umorzeniu śledztwa, b.d.

45 J. Rzendowski, Najdtuższa konspiracja PRL?, „Biuletyn Instytutu Pamięci Narodowej”3, 2004, s. 43.

46 M.P. z 1950 r. Nr A-83, poz. 986; M.P. z 1955 r. Nr 54, poz. 638. 
i zapowiada jego zniszczenie" 47 . Pisma rzeczonego związku wyznaniowego były w ocenie cenzorów ,jątrzące”, miały „napastliwy charakter i destrukcyjny cel”, gdyż poruszały temat niewoli, politycznych kłamstw, traktowały o „zagrożeniu całej ziemi niewolą”, „międzynarodowej bezbożności”, „wtargnięciu materializmu i innych -izmów”, zapowiadały „wieczne zniszczenie władzy totalistycznej” oraz „wyprowadzenie więźniów z totalistycznych systemów”, rozpowszechniały tezy antynarodowe, antypartyjne i antypaństwowe"48. Ponadto pisma Świadków Jehowy uciekały się „do obelgi na [...] osobę Stalina”, nawoływały do „przeciwstawienia się społeczeństwa organom władzy", groziły zniszczeniem narodu, atakowały „praworządność naszego sądownictwa” i wzywały do nieuczestniczenia w życiu politycznym ${ }^{49}$.

Naczelnik z Gdańska stwierdził, że tego typu pisma są wyrazem nienawiści wobec komunizmu, a wizja Armagedonu — a więc III wojny światowej, w wyniku której zginie prawie cała ludzkość z wyjątkiem Świadków Jehowy - ma wzbudzić niepewność jutra, oderwać od budowy socjalizmu i zachęcić do bierności ${ }^{50}$. Lektura tego pisma miała, zdaniem cenzora, wywoływać niepokój i niepewność jutra, oderwać czytelnika od realizacji planów gospodarczych, od pokojowej pracy i obniżyć aktywność społeczno-polityczną narodu.

Pisma Świadków Jehowy recenzowali również cenzorzy z WUKPPiW w Kielcach. Tamtejszy naczelnik w styczniu 1953 roku na zlecenie WUBP pięciokrotnie opiniował kilkadziesiąt broszur. W marcu 1953 roku ten sam urząd wykonał sześć prac specjalnych na zlecenie WUBP. Pracownicy kontroli po raz kolejny poddali ocenie pismo Świadków Jehowy, ulotki rozprowadzane na terenie województwa oraz kilkanaście książek o „wybitnie dywersyjnej treści” ${ }^{51}$. Również pozostałe urzędy kontroli, najczęściej z Koszalina, Gdańska, Poznania, Olsztyna i Opola, analizowały pisma rzeczonej grupy wyznaniowej.

\section{Kontrola bibliotek kościelnych}

Na zlecenie Służby Bezpieczeństwa oraz poszczególnych wydziałów Komitetu Centralnego PZPR inicjowano skierowane przeciw rozmaitym środowiskom kampanie propagandowe, które sprowadzały się do zastraszania oraz poddawania represjom. Były one realizowane przy pomocy aparatu cenzury. Jedną z największych

47 Archiwum Państwowe w Gdańsku (dalej: AP w Gdańsku), Wojewódzki Urząd Kontroli Prasy, Publikacji i Widowisk w Gdańsku (dalej: WUKPPiW w Gdańsku), 1214/ 3724, k. 37.

48 Ibidem, k. 38-39.

49 Ibidem.

50 Ibidem, k. 44.

51 AAN, GUKPPiW, sygn. 10, sprawozdania okresowe WUKPPiW za rok 1953 (Białystok, Bydgoszcz, Gdańsk, Katowice, Stalinogród, Koszalin, Kielce, Lublin, Łódź), k. 58. Zob. również A. Namysło, Tchórze? Szpiedzy? Wywrotowcy?. Władze województwa śląkiego wobec Świadków Jehowy w pierwszych latach powojennych, „Biuletyn Instytutu Pamięci Narodowej” 3, 2004, s. 55. 
akcji wymierzonych w zgromadzenia zakonne, przeprowadzoną pod nadzorem GUKPPiW, była ogólnopolska kontrola bibliotek kościelnych, która odbyła się w sierpniu 1960 roku. Rewizją objęto biblioteki zakonne oraz diecezjalne niższych i wyższych seminariów duchownych, a także niektóre księgozbiory innych instytucji kościelnych. Za akcję odpowiedzialny był Główny Urząd Kontroli Prasy, Publikacji i Widowisk we współpracy z Urzędem do spraw Wyznań, Ministerstwem Oświaty, KC i KW PZPR, a także MO i SB. Akcja, przygotowywana w wielkiej tajemnicy, rozpoczęła się w całym kraju, a 12 tysięcy zarekwirowanych wówczas książek trafiło do WUKPPiW ${ }^{52}$. Tego typu kontrole nie należały do rzadkości, na przykład w 1955 roku przeprowadzono rewizję w bibliotece należącej do opolskich oo. jezuitów, skąd skonfiskowano kilkadziesiąt publikacji w języku niemieckim i polskim. Wśród zajętych książek i broszur znalazły się między innymi takie pozycje, jak Precz z komunizmem, Front bezbożnictwa komunistycznego, Socjalizm moralna ruina społeczeństwa ${ }^{53}$.

Pracownicy aparatu kontroli przykładali szczególną wagę do kontroli drukarni katolickich, zazwyczaj niewielkich, liczących jedną maszynę starego typu, ustawioną w pomieszczeniach przykościelnych. Naczelnik WUKPPiW w Gdańsku w sprawozdaniu za luty 1953 roku napisał, że cenzorzy położyli bardzo duży nacisk na kontrolę drukarni katolickich, czego efektem było zaplombowanie trzech powielaczy oraz skierowanie sprawy do prokuratora. Zaznaczył, że cenzorzy wykonywali swoje obowiązki w chwilach wolnych od pracy, a efekty uznano za spore „osiągnięcie" 54 . Cenzorzy kontrolowali drukarnie, nawet jeśli maszyny zostały wcześniej zaplombowane i obowiązywał zakaz ich używania. Celem takiego działania było sprawdzenie, czy rzeczywiście znajdują się w stanie unieruchomienia. Aby przekonać się, czy nikt z nich nie korzystał, cenzorzy dokładnie oglądali założone plomby oraz sprawdzali wilgotność matryc zecerskich ${ }^{55}$. W chwilach wolnych od pracy pojawiali się incognito na festynach katolickich, dożynkach i innych imprezach z udziałem duchowieństwa katolickiego i kontrolowali, czy nie rozprowadza się druków niemających zgody cenzury.

Cenzorzy razem z funkcjonariuszami Urzędu Bezpieczeństwa (a także, od czasu do czasu, Milicji Obywatelskiej) przeprowadzali doraźne akcje kontrolne. 27 listopada $1951 \mathrm{roku}$ z polecenia naczelnego dyrektora GUKPPiW, rozpoczęto akcję wycofywania z obiegu „szmirowatych”, jak wyraził się naczelnik WUKPPiW w Gdańsku, oraz nielegalnie drukowanych pocztówek, obrazków, laurek

52 W. Konopka, Rewizje i konfiskaty księgozbiorów zakonnych w Polsce po II wojnie światowej na przykładzie działań władz komunistycznych wobec bibliotek zakonnych $w$ Toruniu w sierpniu 1960 r., [w:] Źródła i materialy do badań nad kasatami klasztorów z obszaru Pomorza Nadwiślańskiego i ziemi chetmińskiej (XIX i XX w.), red. P. Oliński, W. Rozynkowski, Wrocław 2015, s. $225-241$.

53 AAN, GUKPPiW, sygn. 10, sprawozdania okresowe WUKPPiW za rok 1953 (Białystok, Bydgoszcz, Gdańsk, Katowice, Stalinogród, Koszalin, Kielce, Lublin, Łódź), k. 34.

54 Ibidem, k. 64.

55 Ibidem, k. 53 
okolicznościowych (na przykład ślubnych) i dyplomów. Punkty sprzedaży tego typu towaru musiały mieć licencję na produkcję pocztówek wydawaną przez Centralny Urząd Wydawnictw, Przemysłu Graficznego i Księgarstwa oraz pozwolenie na druk i rozpowszechnianie wydane przez miejscowy urząd kontroli. Cenzorzy z wielkimi oporami wydawali zgodę na drukowanie zaproszeń na śluby kościelne, chrzciny, święcenia kapłańskie lub obrazki ze świętymi. W okresie stalinizmu drukowanie zaproszeń, pocztówek i obrazków z motywami religijnymi spadło niemal do zera, a popyt na stare egzemplarze wzrósł. Można je było nielegalnie nabyć w antykwariatach lub bazarach, ale ceny były adekwatne do ryzyka, jakie ponosił sprzedawca. Sprzedaż i kolportaż kart religijnych cenzorzy uznawali za przejaw propagandy klerykalnej. „Naloty” na punkty sprzedaży organizowano głównie w okresach poprzedzających najważniejsze katolickie święta — Trzech Króli, Wielkanocy, Bożego Ciała, Wniebowzięcia Najświętszej Maryi Panny, Wszystkich Świętych i Bożego Narodzenia.

Osiągnięciami na tym polu mógł pochwalić się naczelnik WUKPPiW w Gdańsku, który w sprawozdaniu dla GUKPPiW napisał, że w okresie od 8 do 22 grudnia 1951 roku wycofano z obiegu na terenie Trójmiasta 106585 sztuk pocztówek (z prywatnych sklepów — 14 257, a pozostałe z MHD i magazynu „Domu Książki”). W całym województwie gdańskim usunięto 164933 kartki i przy okazji ujawniono siatkę nielegalnych producentów, dostawców i kolporterów, głównie osób prywatnych zatrudnionych w zakładach fotograficznych, spółdzielniach pracy, hurtowniach artykułów piśmienniczych, wytwórniach artykułów papierniczych i składnicach drobnej wytwórczości. Wykaz nielegalnych instytucji i dostawców kart widokowych, pocztówek oraz laurek liczył 33 pozycje, na które złożyły się dane osób prywatnych (imię, nazwisko oraz adres) lub instytucji (wraz z adresem). Wykazy trafiły następnie do Urzędu Bezpieczeństwa, gdzie zajęto się rozpracowywaniem grupy prywatnych sprzedawców. Wśród skonfiskowanych druków ulotnych znalazły się pocztówki z motywami religijnymi (zmartwychwstanie, święconka), krajobrazowymi (Tatry, Dolina Pięciu Stawów), zwierzęcymi (pies, kot) oraz laurki ślubne i dyplomy ${ }^{56}$.

Kontrola działalności Kościoła odbywała się w ścisłym porozumieniu GUKPPiW, Urzędu do Spraw Wyznań i MBP/MSW, czego liczne dowody znajdują się w sprawozdaniach miesięcznych wysyłanych przez naczelników WUKPPiW do Urzędu Głównego ${ }^{57}$. Na przykład w maju 1953 roku naczelnik gdańskiej cenzury chwalił się centrali, że udało mu się wykryć nielegalną produkcję obrazków świętych i pocztówek z motywami religijnymi. Cenzorzy skonfiskowali klisze i aparaty, a sprawcy najprawdopodobniej trafili do aresztu ${ }^{58}$. Ten sam na-

56 Ibidem, k. 34.

$57 \mathrm{~W}$ sprawozdaniach widnieje nawet specjalna rubryka pod tytułem „Praca na odcinku katolickim".

58 AAN, GUKPPiW, sygn. 10, sprawozdania okresowe WUKPPiW za rok 1953 (Białystok, Bydgoszcz, Gdańsk, Katowice, Stalinogród, Koszalin, Kielce, Lublin, Łódź), k. 34. 
czelnik wspominał również o rozbiciu „dzikiej imprezy amatorskiej” — zespołu Seminarium Duchownego z Pelpina, który wystawił sztukę bez zezwolenia cenzury.

We wrześniu 1953 roku cenzorzy z WUKPPiW w Poznaniu, w porozumieniu z KW PZPR oraz Urzędem Bezpieczeństwa Publicznego, wzięli udział w likwidacji stoiska $\mathrm{z}$ dewocjonaliami znajdującego się u wejścia do kościoła Matki Boskiej Nieustającej Pomocy. Tak o efektach akcji napisał później naczelnik urzędu:

Skonfiskowaliśmy dużo przedwojennej literatury kolportowanej przez 2 kobiety i 1 starca z polecenia zakonnicy - powierniczki księdza proboszcza. Zabraliśmy masę modlitw pisanych na maszynie i powielanych. Udało nam się złapać nielegalnie wydrukowaną nowennę do Judy Tadeusza /patrona rzeczy beznadziejnych/ ${ }^{59}$.

Cenzorzy wraz z funkcjonariuszami UB zarekwirowali również materiały solidacyjne oraz publikacje działającego w podziemiu Katolickiego Stowarzyszenia Młodzieży.

\section{Perlustracja korespondencji i paczek}

Cenzorzy współpracowali ze Służbą Bezpieczeństwa w zakresie oceny książek zarekwirowanych $\mathrm{w}$ urzędach celnych i pocztowych. W drugiej połowie lat pięćdziesiątych i w latach sześćdziesiątych XX wieku analizą rzeczonych publikacji zajmowali się cenzorzy z Samodzielnego Wydziału Obcojęzycznego GUKPPiW oraz poszczególne urzędy terenowe, zatrudniające cenzorów władających językami obcymi (choć należało to do rzadkości, nawet w urzędach „obsługujących” Ziemie Zachodnie). Zarówno GUKPPiW, jak i WUKPPiW współpracowały w zakresie analizy zagranicznych publikacji z Biurem „W” (lub terenowymi odpowiednikami afiliowanymi przy komendach wojewódzkich MO), utworzonym w 1955 roku (od 1956 roku wchodzącym w skład MSW), powołanym do kontroli korespondencji oraz paczek ${ }^{60}$.

Choć w październiku 1956 roku polityka cenzury wobec krajowych środków przekazu uległa czasowemu złagodzeniu, to nie można mówić o takim samym zjawisku w stosunku do książek i czasopism z zagranicy. Zawartość zagranicznych paczek oraz listów była drobiazgowo analizowana, a budzące zastrzeżenia publikacje - potajemnie konfiskowane, bez informowania adresata o zaistniałym fakcie. Paczki, które trafiały do urzędów celnych, były kontrolowane przez pracowników Biura „W” i celników, a konfiskowane publikacje przekazywano bezpośrednio GUKPPiW oraz WUKPPiW. Jak ustalił Piotr Nowak, niejawna perlustracja

59 AAN, GUKPPiW, sygn. 11, sprawozdania okresowe WUKPPiW za rok 1953 (Olsztyn, Opole, Poznań, Rzeszów, Szczecin, Wrocław); recenzje książek, pisma instrukcyjne, k. 223.

${ }^{60}$ P. Nowak, Kto w życiu myśli, nie pisze nic... Krótka historia perlustracji w Polsce, Poznań 2016, s. 73. 
odbywała się zarówno w budynkach urzędów pocztowych, jak i w pomieszczeniach Służby Bezpieczeństwa, a nawet specjalnie wytypowanych do tego celu pomieszczeniach, takich jak prywatne mieszkania tajnych współpracowników ${ }^{61}$. Korespondencję sortowali pracownicy poczty, działający w charakterze tajnych współpracowników SB, natomiast kontroli merytorycznej dokonywali esbecy oraz cenzorzy. Dostarczone cenzorom publikacje były analizowane przez pracowników Samodzielnego Wydziału Obcojęzycznego (SWO) GUKPPiW, którzy decydowali, czy prasa i książki trafią do adresata, czy też „na przemiał”. GUKPPiW współpracował również z Biurem Rejestracji Cudzoziemców MSW, które przekazywało cenzorom informacje na temat charakteru pobytu i terminu ważności wiz cudzoziemców przebywających w PRL, na których adres przysyłane były obcojęzyczne książki oraz czasopisma ${ }^{62}$.

Raporty sporządzane przez pracowników SWO GUKPPiW na potrzeby poszczególnych ministerstw, wydziałów KC PZPR oraz Służby Bezpieczeństwa wskazują, jak wiele paczek wypełnionych książkami i prasą przysyłano wówczas Polakom z zagranicy. W raportach SWO znajdują się między innymi informacje o skali „akcji dywersyjnej”, jak ją nazywano, tematyce publikacji, kierunkach, z których je nadsyłano, oraz ośrodkach, wydawnictwach i instytucjach, które to czyniły. Aby zilustrować skalę konfiskowanych publikacji, warto przybliżyć informacje statystyczne. Poniższe dane dotyczą wyłącznie Urzędu Wymiany Poczty Warszawa 3, placówki obsługującej pocztę zagraniczną, więc skala potajemnie konfiskowanych listów i paczek była znacznie większa. Od 1 stycznia do 30 września 1958 roku skonfiskowano 35 tysięcy druków religijnych $(50 \%$ w języku niemieckim), zaś od 1 września 1958 roku do 15 marca 1959 roku 53731 periodyków63. W 1960 roku wzrosła liczba „koniecznych włączeń”, jak w cenzurze nazywano konfiskaty, z 79 do $81 \%$ (w liczbach bezwzględnych wynosiła 9400 egzemplarzy) ${ }^{64}$. Oznacza to, że funkcjonariusze SB wespół z cenzorami konfiskowali osiem na dziesięć nadsyłanych do wspomnianego urzędu publikacji (nie wliczając do statystyk obrazków ze świętymi, których miesięcznie nadsyłano średnio około 45 tysięcy). W dniach między 1 stycznia a 15 grudnia 1960 roku cenzorzy skonfiskowali 80 tysięcy książek, 11700 płyt, 10 tysięcy czasopism i 35 tysięcy ulotek religijnych, które przysłano do Polski z RFN ${ }^{65}$. Konfiskacie podlegały również czasopisma posiadające debit komunikacyjny, a więc takie, które przynajmniej teoretycznie miały prawo być kolportowane na terytorium PRL. Ze statystyk GUKPPiW wynika, że między 1 stycznia a 30 czerwca 1960 roku cenzorzy, z pomocą SB, skonfiskowali 71 tytułów prasowych przysyłanych

61 Ibidem, s. 79.

62 IPN BU 1585/1151, k. 2.

63 AAN, GUKPPiW, sygn. 4079, działalność Samodzielnego Wydziału Obcojęzycznego. Notatki, uwagi dotyczące zatrzymanych i kontrolowanych publikacji, k. 53.

64 Ibidem, k. 78.

65 Ibidem, k. 98 
do kraju w ramach prenumeraty. Były to głównie niemieckie, brytyjskie, włoskie i francuskie czasopisma społeczno-polityczne ${ }^{66}$.

\section{Kontrola jakości ocenzurowanego przekazu medialnego}

Współpraca cenzorów ze Służbą Bezpieczeństwa trwała przez cały okres PRL. Z relacji Tomasza Strzyżewskiego wynika, że w latach siedemdziesiątych XX wieku dyrektor krakowskiej delegatury GUKPPiW mniej więcej raz w tygodniu spotykał się z funkcjonariuszem SB. Do takich spotkań dochodziło w siedzibie urzędu i trwały one około godziny ${ }^{67}$. Zaznaczyć należy, że funkcjonariusz SB kontaktował się wyłącznie z dyrektorem (Tadeuszem Leśniakiem) lub wicedyrektor (Anną Siwek), nigdy zaś z szeregowymi cenzorami (zatrudnionymi na stanowiskach radców lub starszych radców). Jaki był cel takich spotkań? Zdaniem byłego pracownika krakowskiej delegatury GUKPPiW

była to jakaś forma inwigilacji polegająca na sprawdzaniu „prawomyślności” funkcjonariuszy ówczesnego ośrodka Czwartej Władzy, czyli redaktorów, dziennikarzy oraz publicystów, poprzez analizę ingerencji cenzorskich, jakie delegatura musiała dokonywać [...] w tekstach przedkładanych do kontroli ${ }^{68}$.

Można sformułować tezę, że rola cenzury sprowadzała się w gruncie rzeczy do kontroli jakości przekazu medialnego, ocenzurowanego uprzednio przez dziennikarzy i redaktorów, którzy na ogół zdawali sobie sprawę, gdzie leżą granice tolerancji cenzorów. Warto zacytować dłuższą wypowiedź Strzyżewskiego, który zwrócił uwagę, iż cenzura państwowa była jednym z elementów zawiłego procesu kontroli przekazu medialnego, w którym dziennikarze odgrywali znaczącą rolę. Strzyżewski wyraził pogląd, że (podkreślenia oryginalne):

Właściwymi lub bezpośrednimi producentami tego ocenzurowanego przekazu byli zatrudniający się w tej fabryce redaktorzy, dziennikarze i publicyści, którzy sprawowali tam tzw. cenzurę wewnętrzną w odróżnieniu od cenzury zewnętrznej sprawowanej przez GUKPPiW. A ta wewnętrzna cenzura odpowiadała za ponad $90 \%$,ingerencji cenzorskich" i to nie tylko w sensie ilościowym, ale może przede wszystkim w sensie ich „ciężaru gatunkowego" mierzonego stopniem opiniotwórczegozagrożenia dla totalitarnej władzy. [...] Warunkiem wykonywania w PRL-u zawodu dziennikarza lub redaktora była nie tylko akceptacja cenzury ale także stosowanie jej samemu. Wskutek tego nie pracowali tam ani antykomuniści, ani też zwolennicy tzw. wolności słowa, lecz tylko prawdziwi (z krwi i kości) CENZORZY. Każdy bez wyjątku redaktor czy dziennikarz zatrudniony w peerelowskich mediach był po pierwsze cenzorem, ale z drugiej był też Tajnym Współpracownikiem (TW) GUKPPiW. Tajność ta wynikała z faktu dobrowolnego poddawania się procedurom przekazywania oraz odbioru własnych lub pisanych przez ich podwładnych tekstów

\footnotetext{
66 Ibidem, k. 94.

67 Relacja Tomasza Strzyżewskiego z listopada 2018 roku.

68 Relacja Tomasza Strzyżewskiego ze stycznia 2020 roku.
} 
do skontrolowania przez „radców” GUKPPiW, które to procedury utajniały fakt tej współpracy ${ }^{69}$.

Weryfikacja prawomyślności ówczesnych dziennikarzy przeprowadzana przez Służbę Bezpieczeństwa nie była zatem konieczna, co rzecz jasna nie oznacza, że takowa nie miała miejsca. Ze wspomnień Andrzej Bobera, wieloletniego dziennikarza między innymi „Życia Gospodarczego” i „Życia Warszawy”, wynika, że Służba Bezpieczeństwa interesowała się cenzorami w sytuacjach, kiedy przeoczenia prowadziły do ośmieszania czynników państwowych lub sojuszników PRL. Jak wspominał dziennikarz, z pracy w „Życiu Warszawy” (1965-1979) utkwiły mu w pamięci dwie sytuacje związane z cenzurą i wejściem pracowników bezpieczeństwa na teren redakcji. W pierwszym przypadku przyczyną ,nalotu" SB miało być umieszczenie w prognozie pogody na dzień następny zdania „wiatry z kierunków wschodnich”. Tak to wspominał Bober:

I od rana redakcja pełna esbeków: kto to wymyślił, kto za to odpowiada, wywalić z pracy... Szczęśliwie dyżur tamtego dnia miała Ryszarda Kazimierska (sekretarz Podstawowej Organizacji Partyjnej PZPR), która musiała być, z automatu, poza wszelkim podejrzeniem. Rysia więc ocalała, ale wywalono z pracy cenzora, który to puścif ${ }^{70}$.

Druga sytuacja dotyczyła anonsu, który ukazał się w rubryce z ogłoszeniami w „Życiu Warszawy”:

Innego dnia przyjeżdżam rano do pracy, a tu znowu nalot esbeków. Węszą w papierach naszego Biura Ogłoszeń. Okazało się, że w rubryce ogłoszeń ukazał się anons: „Małe fiaty przerabiam na gokarty. Telefon: 628 ...". A to był numer ministra przemysłu maszynowego Tadeusza Wrzaszczyka, podobno ojca chrzestnego „maluchów”. W redakcji nie znaleziono winnych, cenzorów pouczono, że trzeba sprawdzać, i od tamtego dnia wprowadzono przepis: każdy dający jakiekolwiek ogłoszenie musi wylegitymować się dowodem osobistym, którego numer będzie zapisany... ${ }^{71}$

Przypadki surowego karania cenzorów za błędy polityczne (w tym zecerskie) zakończyły się wraz ze stalinizmem, choć jak wskazują przywołane wspomnienia, pojedyncze przypadki zdarzały się także w późniejszych latach. Ze wspomnień cenzora z GUKPPiW zatrudnionego w latach 1974-1977 wynika, że w przypadku tak zwanych przeoczeń, a więc dopuszczania do druku publikacji (w całości, fragmentów lub poszczególnych zdań i wyrazów) politycznie „szkodliwych”, szeregowy cenzor nie ponosił odpowiedzialności. „Nie przypominam sobie, aby ktoś z powodu przeoczenia wyleciał z pracy albo w ogóle miał jakieś większe nieprzyjemności. Nieprzyjemności miał prezes. Pamiętam, że czasem dzwonił

69 Relacja Tomasza Strzyżewskiego z lutego 2020 roku.

70 A. Bober, Machina cenzury, „Karta” 101, 2019, s. 99.

71 Ibidem. Zob. również Zawodowiec. Andrzej Bober w rozmowie z Beata Modrzejewska, Warszawa 2015, s. 57-59. 
z pretensjami bezpośredni do firmy premier Jaroszewicz, ale dla szeregowego cenzora nic z tego nie wynikało" - mówił cenzor ${ }^{72}$.

Podobną opinię wyraził Tomasz Strzyżewski, który w trakcie osiemnastu miesięcy pracy w krakowskiej delegaturze GUKPPiW nie spotkał się z przypadkiem, aby przeoczenie cenzora zakończyło się dochodzeniem KW PZPR lub SB. Było to konsekwencją faktu, iż cenzorzy czytali teksty prasowe uprzednio ocenzurowane przez samych autorów ${ }^{73}$.

\section{Résumé}

Zakres współpracy cenzorów z UB/SB był w latach czterdziestych, pięćdziesiątych i sześćdziesiątych XX wieku szerszy niż w późniejszych dekadach. W rzeczonym okresie cenzorzy traktowali swoje kontakty z pracownikami aparatu represji jako zawodowy obowiązek, rzecz naturalną i wskazaną, tak jak kontakty z poszczególnymi wydziałami KW lub KM PZPR. Zaznaczyć jednak należy, że do kontaktów między cenzorami a pracownikami UB/SB dochodziło przeważnie na szczeblu dyrektorskim, to znaczy szeregowy cenzor nie miał styczności z funkcjonariuszami aparatu represji. Z relacji Tomasza Strzyżewskiego i innych źródeł wynika, że z biegiem czasu nie uległo to zmianie, za kontakty z SB odpowiadali dyrektorzy urzędów kontroli, nie zaś szeregowi cenzorzy, którzy mogli nawet nie wiedzieć, że dyrektora odwiedza funkcjonariusz ${ }^{74}$.

Cenzorzy byli dla UB/SB nader cennym źródłem informacji: o dziennikarzach, pisarzach, pracownikach nauki oraz innych osobach mających styczność ze słowem drukowanym. O informacjach gromadzonych na potrzeby aparatu władzy mówił w wywiadzie opublikowanym w 1981 roku na łamach „Tygodnika Solidarność" cytowany już cenzor, zatrudniony w pionie instruktażu GUKPPiW. Jego wypowiedź wskazuje, jak ważnym źródłem informacji byli dla aparatu władzy pracownicy kontroli:

Ja konkretnie zajmowałem się sporządzaniem informacji, co danego dnia zostało zdjęte, jakie były najdrobniejsze ingerencje $\mathrm{w}$ danym tekście. Ta komórka to był apel cenzury do mocodawców, aby zainteresowali się tym, co jest w gazetach. [...] Wszystko do nich szło, nic nie było przemilczane. Do moich zajęć należało właśnie jak najskrupulatniejsze przedstawianie tych tekstów. I te postulaty, i te sprawy, które teraz tak zalały umęczoną ojczyznę — to wszystko, co wyście wyszperali, a my zdejmowaliśmy, szło codziennie elegancko wypunktowane [...] do wydziału prasy KC, naprzeciwko. Czyli jest ewidentną nieprawdą, że władza się nie orientowała. Wiedzieli wszystko. [...] ja miałem codziennie na biurku wszystko, co zostało zdjęte w PRL. Byłem bardzo dobrze poinformowany ${ }^{75}$.

72 Ja, cenzor, rozmowa przeprowadzona przez Barbarę N. Łopieńską, „Tygodnik Solidarność" 6, 1981, s. 6 .

73 Relacja Tomasza Strzyżewskiego z lutego 2020 roku.

74 Relacja Tomasza Strzyżewskiego ze stycznia 2020 roku.

75 Ja, cenzor..., s. 6. 
Należy przypuszczać, że wykazy ocenzurowanych oraz odrzuconych w całości tekstów trafiały również do funkcjonariuszy Służby Bezpieczeństwa.

\section{Bibliografia}

\section{Źródła archiwalne}

Archiwum Akt Nowych w Warszawie

Główny Urząd Kontroli Prasy, Publikacji i Widowisk:

— sygn. 10, sprawozdania okresowe WUKPPiW za rok 1953 (Białystok, Bydgoszcz, Gdańsk, Katowice, Stalinogród, Koszalin, Kielce, Lublin, Łódź);

— sygn. 11, sprawozdania okresowe WUKPPiW za rok 1953 (Olsztyn, Opole, Poznań, Rzeszów, Szczecin, Wrocław), recenzje książek, pisma instrukcyjne;

— sygn. 24, Biuletyn Informacyjno-Instrukcyjny nr 1 (I 1955) - nr 11/12 (XII 1955);

— sygn. 4079, Działalność Samodzielnego Wydziału Obcojęzycznego. Notatki, uwagi dotyczące zatrzymanych i kontrolowanych publikacji.

Archiwum Instytutu Pamięci Narodowej w Warszawie

Ministerstwo Spraw Wewnętrznych:

- sygn. 0648/154/1, t. 1 ,

— sygn. 01251/533, doniesienie TW „Piotra”, 20 X 1964;

- sygn. 01251/533, notatka służbowa, 30 IV 1965;

— sygn. 01251/533, pismo do MSW, 14 II 1965;

— sygn. 01251/533, wniosek o założenie sprawy, 28 I 1965;

- sygn. 01251/533, notatka opracowana na podstawie opinii t.w. dot. autorstwa publika-

cji „Kultury” paryskiej, podpisywanych ps. „Gaston de Cerizay”, 29 X 1964;

— sygn. 01251/533, akt oskarżenia, XI 1965;

— sygn. 01251/533, postanowienie o umorzeniu śledztwa, b.d.

Archiwum Państwowe w Gdańsku

Wojewódzki Urząd Kontroli Prasy, Publikacji i Widowisk w Gdańsku:

— sygn. 1214/3724.

Archiwum Ośrodka KARTA w Warszawie

Kolekcja Anieli Steinsbergowej. Sprawy sądowe własne: Hanna Rewska:

— sygn. AO III/214K.11.39, akt oskarżenia A. Rewskiej;

— sygn. AO III/214K.11.39, protokół przesłuchania podejrzanej A. Rewskiej.

Archiwum Instytutu Literackiego w Maisons-Laffitte

Korespondencja Jerzego Giedroycia z Anną Rewską:

— List A. Rewskiej do J. Giedroycia, 19 III 1956.

Korespondencja Jerzego Giedroycia ze Stanisławem Mackiewiczem.

\section{Opracowania}

Cerizay de G., Polska Gomulki i list 34, „Kultura” 10, 1964.

Jaruzelski J., Stanisław Cat-Mackiewicz 1896-1966. Wilno-Londyn-Warszawa, Warszawa 1987.

Kamińska-Chełminiak K., Cenzura w Polsce 1944-1960. Organizacja, kadry, metody pracy, Warszawa 2019.

Konopka W., Rewizje i konfiskaty księgozbiorów zakonnych w Polsce po II wojnie światowej na przyktadzie działań władz komunistycznych wobec bibliotek zakonnych $w$ Toruniu $w$ sierpniu

Studia nad autorytaryzmem i totalitaryzmem 42, nr 3, 2020

(C) for this edition by CNS 
1960 r., [w:] Źródła i materiały do badań nad kasatami klasztorów z obszaru Pomorza Nadwiślańskiego i ziemi chetmińskiej (XIX i XX w.), red. P. Oliński, W. Rozynkowski, Wrocław 2015. Namysło A., Tchórze? Szpiedzy? Wywrotowcy?. Władze województwa śląkiego wobec Świadków Jehowy w pierwszych latach powojennych, „Biuletyn Instytutu Pamięci Narodowej” 3, 2004.

Nowak P., Kto w życiu myśli, nie pisze nic... Krótka historia perlustracji w Polsce, Poznań 2016.

Patelski M., Cenzura komunistyczna wobec Kościoła katolickiego i prasy katolickiej w Polsce. Casus Śląska Opolskiego, [w:] Cenzura w PRL. Analiza zjawiska, red. Z. Romek, K. Kamińska-Chełminiak, Warszawa 2017.

Patelski M., „Czujni strażnicy demokracji” ludowej. Urząd cenzury w województwie opolskim 1950-1990, Opole 2019.

Pawlikowski M.K., Stanisław Mackiewicz w listach do przyjaciela, „Kultura” 5, 1967.

Rzendowski J., Najdluższa konspiracja PRL?, „Biuletyn Instytutu Pamięci Narodowej” 3, 2004.

Siedlecka J., Obława. Losy pisarzy represjonowanych, Warszawa 2005.

Werblan A., Stalinizm w Polsce, Warszawa 2009.

\section{Źródła publikowane}

Aparat bezpieczeństwa w Polsce. Kadra kierownicza 1944-1956, t. 1, red. K. Szwagrzyk, Warszawa 2005.

Księga bezprawia. Akta normatywne kierownictwa Resortu Bezpieczeństwa Publicznego (19441956), wyb. i oprac. B. Kopka, wstęp A. Paczkowski, Warszawa 2011.

Represje wobec duchowieństwa górnoślaskiego w latach 1939-1956 w dokumentach, wyb., wstęp i oprac. K. Banaś, A. Dziurok, Katowice 2003.

Sąd orzekt..., Paryż 1972.

Sprawozdania Sekcji 5 Wydziału V Wojewódzkiego Urzędu Bezpieczeństwa Publicznego w Krakowie 1946-1952, red. F. Musiał, Kraków 2008.

\section{Wspomnienia, wywiady, relacje}

Bober A., Machina cenzury, „Karta” 101, 2019.

Ja, cenzor, wywiad przeprowadzony przez Barbarę N. Łopieńską, „Tygodnik Solidarność” 6, 1981. Marchewka A., , ,...Nadejdzie kiedyś dzień wolności”. Wspomnienia, Częstochowa 2008.

Relacja Tomasza Strzyżewskiego z listopada 2018 roku.

Relacja Tomasza Strzyżewskiego ze stycznia 2020 roku.

Relacja Tomasza Strzyżewskiego z lutego 2020 roku.

Torański B., Knebel. Cenzura w PRL-u, Warszawa 2016.

Zawodowiec. Andrzej Bober w rozmowie z Beata Modrzejewska, Warszawa 2015.

\section{Akty prawne}

Dekret z dnia 13 czerwca 1946 roku o przestępstwach szczególnie niebezpiecznych w okresie odbudowy Państwa, Dz.U. z 1946 r. Nr 30, poz. 192.

Zarządzenie Naczelnego Dyrektora Głównego Urzędu Kontroli Prasy, Publikacyj i Widowisk z dnia 20 lipca 1950 roku o pozbawieniu debitu komunikacyjnego, M.P. z 1950 r. nr A-83, poz. 986.

Zarządzenie Prezesa Głównego Urzędu Kontroli Prasy, Publikacji i Widowisk z dnia 3 czerwca 1955 roku o pozbawieniu debitu komunikacyjnego, M.P. z 1955 r. Nr 54, poz. 638. 